\title{
Uji Efektivitas Ekstrak Kulit Manggis (Garcinia mangostana L.) terhadap Fusarium oxysporum pada Kecambah Kelapa Sawit
}

\section{(Effectivity Test of Mangosteen Peel Extract [Garcinia mangostana L.] on Fusarium oxysporum in Oil Palm Seedling)}

\author{
Tyas Dwi Chintya ${ }^{1)^{*}}$, Albertus Sudirman ${ }^{2)}$, Ersan $^{2)}$ \\ 1) Program Studi Produksi dan Manajemen Industri Perkebunan, Jurusan Budidaya Tanaman \\ Perkebunan, Politeknik Negeri Lampung, Jl. Soekarno Hatta No.10 Rajabasa, Bandar Lampung, \\ 35144, Telp.: (0721) 703995, Fax.: (0721) 787309 dan ${ }^{2)}$ Jurusan Budidaya Tanaman Perkebunan, \\ Politeknik Negeri Lampung, Jl. Soekarno Hatta No.10 Rajabasa, Bandar Lampung, 35144, Telp.: \\ (0721) 703995, Fax.: (0721) 787309 \\ E-mail: tyasdwichintya@gmail.com
}

\begin{abstract}
Fusarium oxysporum is a pathogen that causes wilt in oil palm and can cause oil palm sprout decay. The study aimed to determine the effectivity of mangosteen peel extract (Garcinia mangostana L.) in inhibiting the growth of Fusarium oxysporum in vitro and in vivo. The research was conducted in November 2017 to June 2018 at the Politeknik Negeri Lampung. The method used was a completely randomized design (CRD) consisting of 5 treatments, namely the concentration of mangosteen peel extract 0\% (control), 15\%, 30\%, $45 \%$, and $60 \%$. Data were analyzed using analysis of variance (ANOVA) and further tests of mean values using the LSD test. The results showed that mangosteen peel extract affected the percentage of inhibitory zone extract in Fusarium oxysporum in vitro at concentrations of $15 \%, 30 \%$, and $45 \%$ respectively at $25,92 \%, 29,06 \%$ and $35,95 \%$. The treatment of mangosteen peel extract also affected the percentage of disease incidence and number of leaves in in vivo testing.
\end{abstract}

Keywords: botanical fungicide, Fusarium oxysporum, oil palm nursery, pathogen

DOI: http://dx.doi.org/10.25181/jaip.v8i1.1390

Diterima: 11 Oktober 2019 / Disetujui: 27 Februari 2019 / Diterbitkan: 12 Mei 2020

\section{PENDAHULUAN}

Kelapa sawit (Elaeis guineensis Jacq.) merupakan tanaman asli Afrika yang sudah menjadi komoditas pertanian global utama. Selama tiga dasawarsa terakhir konsumsi minyak sawit dunia meningkat tiga kali lipat dari semula. Tahun 2020 mendatang diperkirakan kebutuhan pangan dan energi meningkat sehingga kebutuhan minyak sawit dunia akan mencapai 60 juta ton (Rifai et al., 2014). Upaya meningkatkan produksi kelapa sawit sering terhambat karena adanya serangan penyakit layu yang disebabkan oleh Fusarium oxysporum. Gejala penyakit ini banyak ditemukan pada tajuk dan akar kelapa sawit (Juariyah, Tondok, \& Sinaga, 2018). Kerugian yang ditimbulkan oleh penyakit ini mencapai $20 \%$ pada 38 bulan pertama penanaman kelapa sawit. Cendawan $F$. oxysporum juga mampu menyebabkan busuk kecambah, layu, busuk akar dan perusakan warna pada sistem pembuluh tanaman pada persemaian maupun tanaman yang tua (Horinouchi, Muslim, 
\& Hyakumachi, 2010). Hafizi et al. (2013), berhasil mengisolasi cendawan Fusarium solani dan F. oxysporum dari tanaman kelapa sawit yang terserang penyakit tajuk pada perkebunan kelapa sawit di Malaysia dan sebagian wilayah Sumatera.

Riset pengendalian penyakit yang disebabkan oleh $F$. Oxysporum pada berbagai tanaman telah dilakukan, namun masih terbatas pada tanaman hortikultura misalnya pada cabai (Hutauruk, Suryanto, \& Munir, 2016; Hutauruk, 2018), gladiol (Nuryani et al., 2016), dan bawang merah (Fitriani, Wiyono, \& Sinaga, 2019). Riset pengendalian penyakit akibat F. Oxysporum pada tanaman kelapa sawit belum banyak dilakukan sehingga diperlukan upaya penanganan yang tepat, salah satunya menggunakan fungisida nabati.

Salah satu jenis tanaman yang memiliki kandungan senyawa kimia bermanfaat adalah kulit manggis (Garcinia mangostana L.). Senyawa-senyawa ini merupakan senyawa aktif dari zat bernama xanton yang merupakan zat metabolit sekunder yang terdapat dalam kulit manggis (Jose et al., 2008). Potensi yang dimiliki ekstrak kulit manggis tersebut, tentu menjadi salah satu upaya pengendalian patogen tumbuhan yang ramah lingkungan. Oleh karena itu, perlu dilakukan penelitian mengenai uji efektivitas ekstrak kulit manggis (Garcinia mangostana L.) terhadap Fusarium oxysporum pada kecambah kelapa sawit. Nilai penting penelitian ini adalah membantu upaya pencarian sarana pengendalian penyakit alternatif yang murah, dan efektif terhadap sasaran tetapi aman terhadap lingkungan, khususnya dalam pengendalian penyakit akibat cendawan Fusarium oxysporum pada kecambah kelapa sawit.

\section{METODE PENELITIAN}

Penelitian ini dilaksanakan pada bulan November 2017 sampai dengan Juni 2018 bertempat di Laboratorium Tanaman Perkebunan Politeknik Negeri Lampung, Laboratorium Analisis Politeknik Negeri Lampung, Laboratorium Mikrobiologi Tanah Universitas Lampung, dan Rumah Kaca Politeknik Negeri Lampung. Alat yang digunakan dalam penelitian ini adalah cawan petri diameter $9 \mathrm{~cm}$, tabung reaksi, mikro pipet, jarum ose, cork borer, erlenmeyer, kertas saring, kertas label, kertas tisu gulung, plasticwrap, plastik transparan ukuran $12 \times 25 \mathrm{~cm}$, corong, laminar air flow, rotary evaporator, timbangan analitik, autoclave, shaker, jangka sorong, alumunium foil, gelas ukur, ember, beaker glass, lemari es, panci, kompor gas, pinset, gunting, kapas, dan polybag ukuran $22 \times 14 \mathrm{~cm}$.

Bahan yang digunakan dalam penelitian ini adalah serbuk kulit manggis, biakan murni Fusarium oxysporum strain patogen (koleksi Laboratorium Departemen Proteksi Tanaman Fakultas Pertanian Institut Pertanian Bogor), kentang 500 gram, agar-agar 30 gram, dekstrosa 40 gram, akuades, spiritus, alkohol 70\%, dan kecambah kelapa sawit dari PPKS Medan.

Penelitian dilaksanakan dengan menggunakan Rancangan Acak Lengkap (RAL), yang terdiri atas 5 taraf perlakuan dan 5 ulangan. Perlakuan yang diterapkan adalah konsentrasi ekstrak 
kulit manggis, yaitu kontrol/tanpa ekstrak kulit manggis $\left(\mathrm{P}_{0}\right)$, ekstrak kulit manggis konsentrasi $15 \%\left(\mathrm{P}_{1}\right)$, ekstrak kulit manggis konsentrasi 30\% $\left(\mathrm{P}_{2}\right)$, ekstrak kulit manggis konsentrasi $45 \%\left(\mathrm{P}_{3}\right)$, dan ekstrak kulit manggis konsentrasi $60 \%\left(\mathrm{P}_{4}\right)$.

Pengujian dilakukan secara in vitro dan in vivo. Uji in vitro dilakukan di Laboratorium Mikrobiologi Tanah Universitas Lampung dengan 25 satuan percobaan yang terdiri atas 25 cawan petri yang berisi biakan Fusarium berumur 5 hari, Sedangkan uji in vivo dilakukan di Rumah Kaca Politeknik Negeri Lampung dengan 25 satuan pengamatan yang terdiri atas 25 kecambah kelapa sawit. Dengan demikian total percobaan yang diamati yaitu 50 satuan percobaan. Data hasil diolah secara statistik menggunakan analisis ragam (ANOVA) dan uji lanjut rata-rata nilai tengah menggunakan uji BNT pada taraf nyata $\alpha=5 \%$.

Cara pengujian ekstrak buah manggis terhadap pertumbuhan Fusarium oxysporum dilakukan dengan dua cara, yaitu:

\section{Uji in vitro}

Pengujian in vitro ekstrak kulit manggis dilakukan menggunakan metode uji difusi cakram dengan mengukur zona hambat yang terbentuk. Kertas cakram silinder (diameter $6 \mathrm{~mm}$ ) diteteskan berbagai perlakuan konsentrasi ekstrak sebanyak $10 \mu \mathrm{l}$ menggunakan mikro pipet. Masing-masing konsentrasi ditetesi sebanyak 4 lembar kertas cakram untuk satu cawan petri, sehingga terdapat 100 lembar kertas cakram untuk 25 cawan petri pada uji in vitro.

Kertas cakram yang telah ditetesi konsentrasi ekstrak disusun pada cawan petri di atas permukaan media PDA menggunakan pinset steril. Penyusunan kertas cakram dilakukan pada bagian-bagian pinggir cawan petri. Sedangkan biakan murni Fusarium oxysporum dicetak menggunakan jarum ose pada bagian tengah PDA. Cawan petri selanjutnya diinkubasikan pada suhu $37^{\circ} \mathrm{C}$ selama 5 hari. Kontrol dibuat dengan kertas cakram yang ditetesi akuades dengan perlakuan yang sama. Pengamatan dilakukan setelah 5 hari inkubasi dengan melakukan pengukuran diameter zona bening di sekitar kertas cakram yang dicatat dalam centimeter sebagai diameter zona penghambatan (Wulandari, 2015)

\section{Uji in vivo}

Dua puluh lima isolat murni Fusarium oysporum diuji pada dua puluh lima kecambah kelapa sawit. Sumber inokulum Fusarium oxysporum diperoleh melalui suspensi konidia yang dibuat dengan cara mencampurkan $10 \mathrm{ml}$ akuades ke dalam masing-masing cawan petri yang berisi biakan murni isolat Fusarium oxysporum berumur 2 minggu (Simatupang, 2015). Media tanam yang digunakan adalah tanah sub soil. Tanah terlebih dahulu disterilisasi selama 3 jam, tujuannya agar tanah steril dan terhindar dari cendawan. Kemudian media dimasukkan ke dalam polybag berukuran (20 x 14) cm yang selanjutnya dilakukan inokulasi cendawan dengan cara pelukaan akar.

Inokulasi dilakukan dengan cara merendam kecambah kelapa sawit ke dalam suspensi konidia Fusarium oxysporum selama 1 jam. Kecambah yang telah diinokulasi kemudian ditanam pada polybag berukuran $(20 \times 14) \mathrm{cm}$ berisi media tanah steril. Pemberian ekstrak kulit manggis 
dilakukan 7 hari setelah tanam dengan cara melakukan penyiraman masing-masing konsentrasi ekstrak pada kecambah yang telah ditanam. Pemeliharaan kecambah dilakukan dengan cara penyiraman sebanyak 2 kali sehari penyiraman jangan terlalu basah, supaya tidak memacu pertumbuhan penyakit yang akan mematikan kecambah yang baru tumbuh. Sedangkan penyiangan dilakukan bila sudah terdapat gulma. Pengamatan dilakukan setiap minggu hingga 8 minggu setelah tanam (MST).

Variabel pengamatan yang diamati dalam penelitian ini meliputi:

\section{Diameter Fusarium oxysporum (cm)}

Perhitungan diameter Fusarium oxysporum dilakukan pada 5 hari setelah inokulasi. Perhitungan diameter cendawan menggunakan rumus (Wulandari, 2015):

$$
D A=\frac{(P 1+P 2)}{2}
$$

Keterangan :

$\mathrm{DA}=$ Diameter pertumbuhan cendawan

$\mathrm{P} 1$ = Pertumbuhan sisi cendawan terpanjang

P2 = Pertumbuhan sisi cendawan terpendek

\section{Persentase zona hambat ekstrak (\%)}

Perhitungan persentase zona hambat cendawan Fusarium oxysporum yang bersinggungan dengan konsentrasi ekstrak kulit manggis pada hari ke-5, menggunakan rumus (Muksin, Rosmini, \& Panggeso, 2013):

$$
P A=\frac{(D 1-D 2)}{D 1} X 100 \%
$$

Keterangan :

$\mathrm{PA}=$ Persentase daya hambat $(\%)$

$\mathrm{D} 1$ = Rerata diameter pertumbuhanFusarium oxysporum sebagai kontrol $(\mathrm{cm})$

D2 = Rerata diameter pertumbuhan Fusarium oxysporum pada perlakuan uji konsentrasi ekstrak kulit manggis $(\mathrm{cm})$

\section{Persentase keterjadian penyakit (\%)}

Pada penelitian ini, kecambah yang terserang damati secara morfologi dengan melihat gejala yang diakibatkan oleh Fusarium oxysporum dimulai dari 1 minggu setelah tanam sampai 8 minggu setelah tanam. Perhitungan persentase keterjadian penyakit menggunakan rumus (Simatupang, 2015) sebagai berikut:

$$
\text { Kejadian penyakit }=\frac{\sum \text { tanaman terserang }}{\text { tanaman yang diamati }} \times 100 \%
$$

\section{Tinggi kecambah (cm)}

Pengukuran tinggi kecambah dilakukan dengan menggunakan penggaris mulai dari leher akar hingga titik tumbuh pucuk kecambah selama 2 bulan. Pengukuran tinggi kecambah dilakukan setiap satu minggu sekali. 


\section{Jumlah daun (helai)}

Perhitungan jumlah daun dilakukan 8 minggu setelah tanam dengan cara menghitung total daun yang telah terbuka pada masing-masing perlakuan kecambah kelapa sawit.

\section{HASIL DAN PEMBAHASAN}

\section{Diameter Fusarium oxysporum}

Hasil uji lanjut diameter $F$. oxysporum pada masing-masing perlakuan pada umur 5 hari setelah inokulasi (HSI) dapat dilihat pada Tabel 1.

Tabel 1. Rerata diameter $F$. oxysporum pada tiap perlakuan umur 5 hari setelah inokulasi (HSI)

\begin{tabular}{lc}
\hline \multicolumn{1}{c}{ Perlakuan } & Diameter (cm) \\
\hline Ekstrak kulit manggis 0\% & $3,47 \mathrm{a}$ \\
Ekstrak kulit manggis 15\% & $3,53 \mathrm{a}$ \\
Ekstrak kulit manggis 30\% & $3,38 \mathrm{a}$ \\
Ekstrak kulit manggis 45\% & $3,37 \mathrm{a}$ \\
Ekstrak kulit manggis 60\% & $3,54 \mathrm{a}$
\end{tabular}

Keterangan: Angka-angka yang diikuti oleh huruf yang sama menunjukkan tidak berbeda nyata menurut uji beda nyata terkecil (BNT) pada taraf $\alpha=5 \%$.

Tabel 1 menunjukkan bahwa konsentrasi ekstrak manggis tidak mempengaruhi diameter $F$. oxysporum, namun perlakuan ekstrak $30 \%$ dan $45 \%$ menyebabkan pertumbuhan diameter $F$. oxysporum yang lebih kecil disbanding kontrol. Hal ini diduga karena tingginya konsentrasi yang diberikan maka kandungan senyawa antifungal yang terdapat pada ekstrak kulit manggis juga semakin tinggi sehingga senyawa antifungal yang terserap ke dalam sel-sel $F$. oxysporum akan semakin banyak. Kondisi ini menyebabkan penghambatan yang semakin tinggi terhadap pertumbuhan diameter koloni cendawan $F$. oxysporum.

Pemberian konsentrasi ekstrak kulit manggis 60\% menunjukkan pertumbuhan diameter terbesar yaitu $3.54 \mathrm{~cm}$. Hal ini disebabkan oleh kemampuan ekstrak untuk berdifusi ke dalam media PDA terbatas karena ekstrak terlalu pekat. Menurut Maleki et al. (2008), pada konsentrasi tinggi, ikatan antar molekul semakin kuat sehingga menyebabkan senyawa-senyawa aktif yang terkandung dalam ekstrak yang kental berukuran lebih besar. Ekstrak ini tidak dapat berdifusi ke dalam medium PDA dan dinding sel cendawan. Akibatnya mekanisme perusakan membran sel cendawan oleh senyawa aktif yang dikandung ekstrak manggis tidak maksimal. 


\section{Persentase Zona Hambat}

Hasil uji lanjut untuk mengetahui perlakuan terbaik dari beberapa konsentrasi ekstrak kulit manggis tertera pada Tabel 2. Tabel 2 menunjukkan bahwa persentase zona hambat akibat perlakuan ekstrak kulit manggis dengan konsentrasi 30\% dan $45 \%$ menghasilkan zona hambat tertinggi yaitu $29,06 \%$ dan $35,95 \%$, diikuti oleh ekstrak kulit manggis $15 \%$ yaitu $25,92 \%$, namun pemberian ekstrak kulit manggis dengan konsentrasi $60 \%$ tidak berbeda nyata dengan ekstrak kulit manggis $0 \%$ (kontrol).

Tabel 2. Rerata persentase zona hambat ekstrak kulit manggis terhadap F. oxysporum pada in vitro

\begin{tabular}{lc}
\hline \multicolumn{1}{c}{ Perlakuan } & Persentase zona hambat (\%) \\
\hline Ekstrak kulit manggis 0\% & $14,80 \mathrm{a}$ \\
Ekstrak kulit manggis 15\% & $25,92 \mathrm{~b}$ \\
Ekstrak kulit manggis 30\% & $29,06 \mathrm{c}$ \\
Ekstrak kulit manggis 45\% & $35,95 \mathrm{c}$ \\
Ekstrak kulit manggis 60\% & $17,67 \mathrm{a}$ \\
\hline
\end{tabular}

Keterangan: Angka-angka yang diikuti oleh huruf yang sama menunjukkan tidak berbeda nyata menurut uji beda nyata terkecil (BNT) pada taraf $\alpha=5 \%$.

Kulit manggis mengandung senyawa bioaktif berupa xanton yang bersifat antifungal. Jenis xanton yang paling sering digunakan dalam pengujian antara lain: $\alpha$-, $\beta$-, $\gamma$-mangostin, garsinon $E$, 8-deoksigartanin, dan gartanin (Jose et al., 2008). Mekanisme penghambatan xanton terhadap cendawan belum diketahui namun demikian, menurut Anderson (2005), senyawa ini diduga mampu menyerang struktur dan fungsi sel khususnya pada ergosterol, yaitu komponen utama penyusun lipid pada membran sel cendawan. Ergosterol merupakan komponen penting pada sel cendawan yang tidak ditemukan pada hewan maupun manusia. Ergosterol dianalogikan sebagai kolesterol pada hewan dan manusia. Senyawa ini memiliki peran penting dalam pengaturan fluiditas membran dan sebagai sinyal pembelahan sel, serta dijadikan senyawa fitokimia untuk mengendalikan cendawan.

\section{Persentase Keterjadian Penyakit}

Hasil uji lanjut untuk mengetahui konsentrasi ekstrak kulit manggis yang efektif dalam menghambat keterjadian penyakit pada kecambah kelapa sawit tertera pada Tabel 3. Persentase keterjadian penyakit pada kecambah kelapa sawit yang diberi ekstrak kulit manggis dengan konsentrasi 15\%, 30\%, dan 45\% tidak berbeda nyata pada konsentrasi 60\% dan kontrol (tanpa perlakuan). Persentase keterjadian penyakit pada kecambah kelapa sawit lebih rendah pada kecambah yang diberi perlakuan ekstrak kulit manggis berturut-turut yakni 45\%, 30\%, dan 15\%. Pada konsentrasi 60\% dan kontrol (tanpa perlakuan) persentase keterjadian penyakit menunjukkan persentase tertinggi yang sama yakni sebesar $68 \%$. 
Tabel 3. Rerata persentase keterjadian penyakit akibat pemberian ekstrak kulit manggis

\begin{tabular}{lc}
\hline \multicolumn{1}{c}{ Perlakuan } & Persentase keterjadian penyakit (\%) \\
\hline Ekstrak kulit manggis 0\% & $68,0 \mathrm{~b}$ \\
Ekstrak kulit manggis 15\% & $45,0 \mathrm{a}$ \\
Ekstrak kulit manggis 30\% & $35,0 \mathrm{a}$ \\
Ekstrak kulit manggis 45\% & $30,0 \mathrm{a}$ \\
Ekstrak kulit manggis 60\% & $68,0 \mathrm{~b}$ \\
\hline
\end{tabular}

Keterangan: Angka-angka yang diikuti oleh huruf yang sama menunjukkan tidak berbeda nyata menurut uji beda nyata terkecil (BNT) pada taraf $\alpha=5 \%$.

Keterjadian penyakit dapat digunakan sebagai angka instensitas penyakit yang menyebabkan gejala seperti layu, nekrosis dan busuk kecambah. Hasil pengamatan kejadian penyakit menunjukkan bahwa kecambah kelapa sawit yang diinokulasi dengan metode pelukaan akar dapat memudahkan cendawan dalam melakukan infeksi, karena secara langsung menyediakan jalur untuk masuknya cendawan ke dalam jaringan tanaman. Cendawan yang berhasil masuk ke dalam jaringan tanaman kemudian merusak sistem pengangkutan air dan nutrisi dari akar menuju organ tanaman yang lain, sehingga terjadi kerusakan pada tanaman bagian atas (Horinouchi et al., 2010)

Selain menghasilkan beberapa hormon penting tanaman, akar merupakan tempat diproduksinya metabolit sekunder tanaman. Fungsi metabolit sekunder adalah untuk mempertahankan diri dari kondisi lingkungan yang kurang menguntungkan, misalnya mampu berfungsi untuk mengatasi hama dan penyakit yang menyerang tanaman, menarik polinator, dan sebagai molekul sinyal (Nugroho, 2013). Menezes (2006) menyatakan bahwa tanaman toleran terhadap pertumbuhan cendawan yang terbatas di dalam jaringannya tanpa melakukan mekanisme pertahanan. Hal ini sesuai dengan prinsip segitiga penyakit bahwa kondisi tanaman yang menguntungkan patogen akan memudahkan patogen untuk menimbulkan gejala penyakit.

Senyawa yang bertindak sebagai antimikroba secara umum melakukan aktivitasnya melalui penghambatan pada dinding sel, penghambatan fungsi membran, penghambatan sintesis protein dan nukleat, perubahan molekul protein, serta penghambatan enzim (Mulyadi, Wuryanti, \& Sarjono, 2017). Dalam kulit manggis senyawa xanton, saponin, tanin, dan flavonoid memiliki aktivitas sebagai antimikroba. Xanton dapat memperlambat replikasi sel. Flavonoid mempunyai sifat yang sangat aktif memperlambat pertumbuhan cendawan dengan cara mengganggu proses difusi makanan ke dalam sel, sehingga pertumbuhan cendawan terhenti. Saponin mempengaruhi permeabilitas membran cendawan. Sedangkan tannin bekerja dengan cara mengendapkan protein dan dapat merusak sel sehingga pertumbuhan cendawan terhambat. 


\section{Efektivitas Ekstrak Kulit Manggis terhadap Tinggi Kecambah}

Aplikasi ekstrak kulit manggis dalam berbagai konsentrasi tidak mempengaruhi tinggi kecambah kelapa sawit. Analisis ragam pada pengamatan 1 sampai 8 minggu setelah tanam tidak memberikan perbedaan nyata (Tabel 4).

Tabel 4. Rerata efektivitas ekstrak kulit manggis terhadap tinggi kecambah bibit kelapa sawit

\begin{tabular}{lcccccccc}
\hline \multirow{2}{*}{ Perlakuan } & \multicolumn{7}{c}{ Rerata tinggi kecambah $(\mathrm{cm})$} \\
\cline { 2 - 8 } & 1 MST & 2 MST & 3 MST & 4 MST & 5 MST & 6 MST & 7 MST & 8 MST \\
\hline Ekstrak kulit manggis 0\% & $0,58 \mathrm{a}$ & $1,48 \mathrm{a}$ & $1,86 \mathrm{a}$ & $2,76 \mathrm{a}$ & $4,12 \mathrm{a}$ & $5,62 \mathrm{a}$ & $7,12 \mathrm{a}$ & $8,64 \mathrm{a}$ \\
Ekstrak kulit manggis 15\% & $0,32 \mathrm{a}$ & $1,06 \mathrm{a}$ & $2,14 \mathrm{a}$ & $3,48 \mathrm{a}$ & $4,94 \mathrm{a}$ & $6,42 \mathrm{a}$ & $8,40 \mathrm{a}$ & $9,86 \mathrm{a}$ \\
Ekstrak kulit manggis 30\% & $0,50 \mathrm{a}$ & $1,24 \mathrm{a}$ & $1,76 \mathrm{a}$ & $2,44 \mathrm{a}$ & $4,68 \mathrm{a}$ & $6,44 \mathrm{a}$ & $8,54 \mathrm{a}$ & $9,86 \mathrm{a}$ \\
Ekstrak kulit manggis 45\% & $0,80 \mathrm{a}$ & $1,04 \mathrm{a}$ & $1,36 \mathrm{a}$ & $1,34 \mathrm{a}$ & $2,40 \mathrm{a}$ & $3,42 \mathrm{a}$ & $5,04 \mathrm{a}$ & $5,92 \mathrm{a}$ \\
Ekstrak kulit manggis 60\% & $0,54 \mathrm{a}$ & $0,96 \mathrm{a}$ & $1,22 \mathrm{a}$ & $1,26 \mathrm{a}$ & $1,28 \mathrm{a}$ & $1,46 \mathrm{a}$ & $1,94 \mathrm{a}$ & $2,68 \mathrm{a}$ \\
\hline
\end{tabular}

Keterangan: Angka-angka yang diikuti oleh huruf yang sama menunjukkan tidak berbeda nyata menurut uji beda nyata terkecil (BNT) pada taraf $\alpha=5 \%$.

Perbedaan tinggi antara kecambah kontrol dengan kecambah yang diberi perlakuan ekstrak kulit manggis dimungkinkan disebabkan oleh beberapa faktor, diantaranya tingkat virulensi $F$. oxysporum tersebut, ketahanan kecambah kelapa sawit dan konsentrasi ekstrak yang digunakan. Tingkat virulensi $F$. oxysporum diduga rendah akibat degenerasi isolat yaitu menurunnya daya virulensi isolat karena isolat telah disimpan dalam waktu yang cukup lama. Ditandai dengan pigmentasi koloni Fusarium oxysporum yang berwarna putih keunguan. Warna koloni akan berwarna ungu gelap jika umur koloni makin tua.

\section{Efektivitas Ekstrak Kulit Manggis terhadap Jumlah Daun}

Berdasarkan analisis sidik ragam, diketahui bahwa ekstrak kulit manggis berpengaruh nyata terhadap jumlah daun kecambah kelapa sawit berumur 8 minggu setelah tanam. Hasil uji lanjut efektivitas ekstrak kulit manggis terhadap jumlah daun tertera pada Tabel 5. Pada Tabel 5, diketahui bahwa jumlah daun kelapa sawit 8 minggu setelah tanam tidak berbeda nyata pada konsentrasi ekstrak 15\% dan kontrol (ekstrak kulit manggis 0\%), sedangkan antar perlakuan konsentrasi ekstrak 30\%, 45\%, dan 60\% terdapat perbedaan nyata.

Menurut Pahan (2007), pertambahan daun kelapa sawit dipengaruhi keadaan musim dan tingkat kesuburan tanah. Tanah yang digunakan dalam penelitian ini adalah tanah subsoil. Subsoil adalah lapisan tanah yang berada di bawah lapisan tanah horizon A sehingga ketersediaan bahan organik sangat rendah. Subsoil juga tidak dapat menggantikan peranan media topsoil untuk dijadikan media tanam apabila tidak dikombinasikan dengan bahan organik apapun. 
Tabel 5. Rerata efektivitas ekstrak kulit manggis terhadap jumlah daun kecambah kelapa sawit 8 minggu setelah tanam (MST)

\begin{tabular}{lc}
\hline \multicolumn{1}{c}{ Perlakuan } & Rerata \\
\hline Ekstrak kulit manggis 0\% & $1,80 \mathrm{~b}$ \\
Ekstrak kulit manggis 15\% & $2,20 \mathrm{~b}$ \\
Ekstrak kulit manggis 30\% & $1,20 \mathrm{a}$ \\
Ekstrak kulit manggis 45\% & $1,20 \mathrm{a}$ \\
Ekstrak kulit manggis 60\% & $0,40 \mathrm{a}$ \\
\hline
\end{tabular}

Keterangan: Angka-angka yang diikuti oleh huruf yang sama menunjukkan tidak berbeda nyata menurut uji beda nyata terkecil (BNT) pada taraf $\alpha=5 \%$.

Secara morfologi kelayuan terlihat pada daun bagian bawah yang menguning. Agios (2005) menyatakan bahwa perubahan warna tersebut disebabkan oleh aktivitas patogen yang menimbulkan adanya gangguan kloroplas sehingga menyebabkan penurunan kandungan klorofil pada daun. Perubahan warna kuning dimulai dari tepi daun menuju ke bagian tengah daun. Waktu munculnya gejala penguningan daun bervariasi mulai dari kecambah berdaun satu hingga kecambah berdaun tiga pada minggu terakhir pengamatan. Cendawan $F$. oxysporum juga menghasilkan fitotoksin yang disebut asam fusarat (Fusaric acid) yang bersifat toksik bagi tanaman sehingga menjadi salah satu penyebab tanaman menjadi layu (Smith, 2007)

\section{KESIMPULAN DAN SARAN}

\section{Kesimpulan}

Konsentrasi ekstrak kulit manggis $15 \%, 30 \%$, dan $45 \%$ mampu menghambat pertumbuhan patogen Fusarium oxysporum secara in vitro dan in vivo. Persentase zona hambat ekstrak kulit manggis terhadap Fusarium oxysporum berturut-turut sebesar 25,92\%, 29,06\%, dan 35,95\%.

\section{Saran}

Perlu dilakukan penelitian lanjutan terhadap uji efektivitas ekstrak kulit manggis terhadap Fusarium oxysporum untuk mengetahui cara serta waktu aplikasi yang optimal sehingga potensi penekanannya akan lebih baik.

\section{DAFTAR PUSTAKA}

Agios, G. N. (2005). Plant Pathology (5th ed.). California (US): Elsevier Academic Press.

Anderson, J. b. (2005). Evolution of antifungal drug resistence: Mechanisms and pathogenfitness. Nature Reviews of Microbiology, 3, 547-556.

Balouiri, M., Sadiki, M., \& Ibnsouda, S. K. (2016). Methods for in vitro evaluating antimicrobial 
activity: A review. Journal of Pharmaceutical Analysis, 6(2), 71-79. https://doi.org/10.1016/j.jpha.2015.11.005.

Fitriani, M. L., Wiyono, S., \& Sinaga, M. S. (2019). Potensi kolonisasi mikoriza arbuskular dan cendawan endofit untuk pengendalian layu Fusarium pada bawang merah. Jurnal Fitopatologi Indonesia, 15(6), 228-238.

Hafizi, R., Salleh, B., \& Latiffah, Z. (2013). Morphological and molecular characterization of Fusarium. solani and F. oxysporum associated with crown disease of oil palm. Brazilian Journal of Microbiology, 44(3), 959-968.

Horinouchi, H., Muslim, A., \& Hyakumachi, M. (2010). Biocontrol of fusarium wilt of spinach by the plant growth promoting fungus Fusarium equiseti GF183. Journal of Plant Pathology, 92(150), 249-254.

Hutauruk, D., Suryanto, D., \& Munir, E. (2016). Asai isolat bakteri kitinolitik Bacillus sp. BK17 pada media pembawa tanah gambut dan kompos janjang kelapa sawit dalam menghambat pertumbuhan jamur patogen Sclerotium rolfsii dan Fusarium oxysporum pada kecambah cabai. Jurnal Hama dan Penyakit Tumbuhan Tropika, 16(1), 61-70.

Hutauruk, D. S. (2018). Potensi bakteri kitinolitik NR09 pada beberapa media pembawa dalam menghambat pertumbuhan jamur patogen Sclerotium rolfsii dan Fusarium oxysporum pada benih cabai merah (Capsicum annuum L.). BIOLINK: Jurnal Biologi Lingkungan Industri Kesehatan, 4(2), 138-151.

Jose, C.P., C.R. Noemi., O.I. Marisol., Jasmin, and M. R. (2008). Medical properties of mangosteen (Garcia mangostana). Food and Chemical Toxicolology, 46(1), 3227-3239.

Juariyah, S., Tondok, E. T., \& Sinaga, M. S. (2018). Trichoderma dan Gliocladium untuk mengendalikan penyakit busuk akar Fusarium pada bibit kelapa sawit. Jurnal Fitopatologi Indonesia, 14(6), 196-204.

Maleki, S., Seyyednejad, S. M., Damabi, N. M., \& Motamedi, H. (2008). Antibacterial activity of the fluid Torillis leptophylla against some clinical pathogen. Journal of Biological Science, 11(9), 1286-1289.

Menezes, R. A. A. C. and M. (2006). Identification and pathogenic characterization of endophytic Fusarium species from cowpea seeds. Anais Da Academia Pernambucana de Ciência Agronômica, 3, 203-215.

Muksin, R., Rosmini, \& Panggeso, J. (2013). Uji antagonisme Trichoderma sp. terhadap jamur patogen Alternaria porri penyebab penyakit bercak ungu pada bawang merah secara in-vitro. E-J. Agrotebis, 1(2), 140-144.

Mulyadi, M., Wuryanti, W., \& Sarjono, P. R. (2017). Konsentrasi hambat minimum (KHM) kadar sampel alang-alang (Imperata cylindrica) dalam etanol melalui metode difusi cakram. Jurnal Kimia Sains dan Aplikasi, 20(3), 130. https://doi.org/10.14710/jksa.20.3.130-135.

Nugroho, B. (2013). Efektivitas Fusarium oxysporum F.sp. Cepae avirulen dalam mengendalikan penyakit layu Fusarium pada cabai. Jurnal Agri Sains, 4(7), 65-75.

Nuryani, W., Yusuf, S., Djatnika, I., \& Marwoto, B. (2016). Pengendalian penyakit layu Fusarium pada Subang Gladiol dengan pengasapan dan biopestisida. Jurnal Hortikultura, 21(1), 40-50.

Pahan, I. (2007). Panduan Lengkap Kelapa Sawit. Jakarta: Penerbit Swadaya. 
Rifai, N., Syaukat, Y., Gumbira-Sa'id, E., \& Pertanian, D. T. I. (2014). Dampak pengembangan produk turunan minyak sawit terhadap peningkatan ekspor produk minyak sawit ke pasar Amerika Serikat. Jurnal Agro Ekonomi, 32(2), 107-125.

Simatupang, G. W. (2015). Eksplorasi Dan Uji Patogenisitas Fusarium spp. Asal Rizosfer Kelapa Sawit Di Kebun Percobaan Cikabayan, Bogor, Jawa Barat.

Smith, S. N. (2007). An overview of ecological and habitat aspects in the genus Fusarium with special emphasis on the soil-borne pathogenic forms. Plant Pathology Bulletin, 16, 97-120. Retrieved from http://140.112.183.1/cpps/pdf/16-3/p097-120.pdf.

Wulandari, M. (2015). Uji Daya Antifungi Ekstrak Biji, Daun dan Kulit Pohon Tanjung (Mimusops elengi Linn.) terhadap Patogen Fusarium moniliforme Sheldon pada Biji Jagung. Retrieved from http://repository.unej.ac.id/bitstream/handle/123456789/65672/Ainul Latifah101810401034.pdf? sequence $=1$. 